\title{
PENAFSIRAN KONSEP KORBAN DALAM KASUS KECELAKAAN LALU LINTAS DAN ANGKUTAN JALAN
}

\author{
Yonas Parulian Adityanto \\ Fakultas Hukum, Universitas Airlangga \\ e-mail:yonaspa07@gmail.com
}

\begin{abstract}
ABSTRAK
Penentuan posisi korban dalam adanya kecelakaan lalu lintas merupakan hal yang krusial yang cukup sulit. Ketentuan mengenai kedudukan korban secara khusus telah diatur dalam Undang-Undang No. 22 Tahun 2009 tentang Lalu Lintas dan Angkutan Jalan yang mengatur mengenai konsep korban di mana korban adalah setiap orang yang mengalami kerugian berupa luka berat, maupun kematian yang diakibatkan dari adanya suatu kecelakaan lalu lintas. Konsep korban tersebut apabila dikaitkan dengan kecelakaan lalu lintas maka akan menimbulkan persepsi bahwa siapa saja yang mengalami luka berat atau meninggal dunia akan dipandang sebagai korban yang benar, padahal dalam kecelakaan lalu lintas, dapat saja terjadi bahwa korban adalah sekaligus pelaku yang lalai dalam berkendara. Selain itu, konsep korban yang terdapat dalam Undang-Undang No. 22 Tahun 2009 tentang Lalu Lintas dan Angkutan Jalan menjadi bertentangan dengan konsep korban yang diatur dalam peraturan perundangan yang berlaku di Indonesia sehingga diperlukan adanya penafsiran konsep korban yang komprehensif dalam rangka penegakan hukum yang adil.
\end{abstract}

Kata Kunci: kecelakaan lalu lintas; korban; pelaku; luka berat

\begin{abstract}
Determination of the position of victims in traffic accidents is crucial that quite difficult. Provisions concerning the position of victims specifically been regulated in Act No. 22 Year 2009 on Traffic and Road Transportation concerning the concept of a victim where the victim is anyone who suffered losses in the form of serious injury, or death resulting from the existence of a traffic accident. Concepts relate to those victims of traffic accidents will rise to the perception that anyone who is seriously injured or dies will be seen as a true victim, whereas in a traffic accident, it can happen that the victim and perpetrator was negligent in driving. Besides, the concept of victims contained in the Act No 22 Year 2009 on Traffic and Transportation be contrary to the concept of victim stipulated in applicable laws and regulations in Indonesia so it needed a comprehensive interpretation of the concept of victim in the framework of a fair law enforcement.
\end{abstract}

Keywords: traffic accidents; victims; perpetrators; serious injury

\section{PENDAHULUAN}

Setiap negara yang ada di berbagai belahan dunia memiliki kedaulatan yang tidak bisa dipisahkan dari kehidupan bernegara masing-masing. Kedaulatan adalah suatu simbol pengakuan yang harus dimiliki oleh setiap negara di mana dengan adanya suatu kedaulatan, maka setiap negara memiliki kekuasaan untuk mengatur jalannya pemerintahannya tanpa diganggu gugat oleh pihak manapun.

Dalam rangka mengatur jalannya pemerintahan, diperlukan suatu adanya instrumen yang berguna untuk mengatur tiap-tiap perbuatan yang sifatnya menyeluruh dan mengikat yaitu hukum. Hukum yang merupakan sarana untuk mengatur tentunya 
memiliki kedudukan yang sangat vital mengingat hukum adalah dasar atau asas pokok suatu negara yang berdaulat.

Penempatan hukum sebagai dasar dari suatu negara menjadikan suatu negara menjadi negara hukum. Ketentuan Pasal 1 ayat (3) Undang-Undang Dasar Negara Republik Indonesia Tahun 1945 dengan tegas telah menyatakan bahwa "Negara Indonesia adalah Negara Hukum". Mohammad Yamin menyatakan bahwa Negara Indonesia berdasarkan atas hukum (rechstaat) dan tidak berdasarkan kekuasaan belaka (machtstaat), serta pemerintah didasarkan pada sistem konstitusi dan tidak bersifat absolut. ${ }^{1}$ Konsep negara hukum Indonesia mengandung asas ketuhanan, perikemanusiaan, kebangsaan, kedaulatan rakyat, dan asas keadilan sosial. Aturan yang diterapkan dalam masyarakat harus mencerminkan kesadaran dan rasa keadilan, sesuai dengan Pancasila sebagai kepribadian dan falsafah bangsa Indonesia. ${ }^{2}$

Pada dasarnya, konsep negara hukum merupakan bagian yang tak terpisahkan dari doktrin Rule of Law. Rule of Law terdiri atas tiga unsur yaitu supremasi hukum atau supremacy of law, persamaan di depan hukum atau equality before the law, dan konstitusi yang didasarkan atas hak-hak perseorangan atau the constitution based on individual rights. ${ }^{3}$ Menurut Oemar Seno Adji, karakteristik dari Rule of Law adalah: The principles, institutions and procedures, not always identical, but broadly similar, which the experience and traditions of lawyers in different countries of the world, often having themselves varying political structures and economic backgrounds, have shown to be important to protect the individual from arbitrary government and to enable him to enjoy the dignity of man. ${ }^{4}$

Konsep Rule of The Law pada dasarnya menghasilkan 4 unsur yaitu: a) Bahwa pemerintah dalam melaksanakan tugas dan kewajibannya harus

${ }^{1}$ Simorangkir. (1986). Hukum dan Konstitusi Indonesia. Jakarta: Gunung Agung, h. 186.

${ }^{2}$ Darji Darmodihardjo dan Sidharta. (1999). Pokok-Pokok Filsafat Hukum: Apa dan Bagaimana Filsafat Hukum Indonesia. Jakarta: Gramedia Pustaka Utama, h. 224.

${ }^{3}$ A.V Dicey. The Relation Between Law and Public Opinion, dalam Lilik mulyadi. (2012). Bunga Rampai Hukum Pidana Umum dan Khusus. Bandung: Alumni, h. 128.

${ }^{4}$ Oemar Seno Adjie. (1980). Peradilan Bebas Negara Hukum. Jakarta: Erlangga, h. 14. berdasar atas hukum atau peraturan perundangundangan; b) Adanya jaminan terhadap hak-hak asasi manusia (warga negara); c) Adanya pembagian kekuasaan dalam negara; d) Adanya pengawasan dari badan-badan peradilan (rechtsterlijke controle). ${ }^{5}$

Kegiatan yang paling umum dilakukan oleh setiap orang adalah dalam hal transportasi. Hampir dapat dipastikan bahwa kegiatan masyarakat sebagian besar membutuhkan transportasi. Proses transportasi dilakukan dengan menggunakan berbagai macam kendaraan bermotor di jalan, udara dengan pesawat, maupun laut dengan kapal. Transportasi yang umum dilakukan sebagian besar adalah dengan melalui darat menggunakan kendaraan bermotor, maka diperlukan adanya rambu-rambu lalu lintas guna menjamin lancarnya kegiatan transportasi masyarakat. Selain daripada rambu-rambu lalu lintas, perlu juga adanya suatu peraturan yang mencakup seluruh aspek kegiatan transportasi masyarakat, terlebih lagi untuk melindungi hak-hak pengguna lalu lintas baik yang sebagian besar didominasi oleh penggunaan kendaraan bermotor. Berangkat dari pemikiran akan pentingnya suatu payung hukum yang sifatnya mencakup keseluruhan akan lalu lintas, maka terbitlah peraturan perundangan yaitu UndangUndang Nomor 22 Tahun 2009 tentang Lalu Lintas dan Angkutan Jalan (selanjutnya disebut UULLAJ).

Terbitnya peraturan perundangan di bidang transportasi dengan disahkannya UULAJ tentu merupakan suatu sarana untuk mengatur sekaligus memberikan perlindungan hukum bagi setiap anggota masyarakat pengguna jalan. Namun demikian, terdapat kejadian-kejadian di dalam kegiatan transportasi masyarakat yang menimbulkan adanya ketimpangan sosial. Dalam kegiatan transportasi, masalah kecelakaan lalu lintas tidak dapat dikesampingkan dan terkadang sulit dihindari. Kecelakaan lalu lintas merupakan keadaan yang membutuhkan perhatian khusus mengingat dalam kecelakaan lalu lintas, timbulnya korban kecelakaan lalu lintas merupakan hal yang hampir dapat dipastikan. Hal ini pasti juga diikuti adanya kerugian baik kerugian materil maupun imateriil. Keadaan ini merupakan keadaan yang terkadang menimbulkan kesulitan tersendiri, terutama bagi pihak kepolisian selaku penyidik dalam kecelakaan

\footnotetext{
${ }^{5}$ Sri Soemantri Martosoewignjo. (1992). Bunga Rampai Hukum Tata Negara Indonesia. Bandung: Alumni, h. 29.
} 
lalu lintas. Kesulitan yang timbul tentunya dalam hal menetapkan posisi pelaku maupun korban dalam kecelakaan lalu lintas.

Posisi pelaku maupun korban yang terjadi dalam kecelakaan lalu lintas terkadang menimbulkan kesulitan tersendiri. Dalam realita yang terjadi, sebagai contoh, kecelakaan antara mobil dan sepeda motor yang sering terjadi di jalan raya. Seringkali pihak pengendara mobil dalam kecelakaan tersebut merupakan pihak pelaku dan pengendara sepeda motor menjadi pihak korban kecelakaan lalu lintas tanpa melihat faktor penyebab kecelakaan, walaupun dalam kecelakaan lalu lintas dapat saja diakibatkan karena pengendara sepeda motor yang lalai mematuhi aturan lalu lintas hingga menyebabkan kecelakaan lalu lintas dengan menabrak mobil. Dalam hal ini, tentu saja pihak pengendara mobil menjadi pihak yang dirugikan dalam kecelakaan lalu lintas.

Di dalam menentukan posisi korban dalam kecelakaan lalu lintas tentunya harus mengacu pada peraturan perundangan. Namun demikian, dalam peraturan perundangan mengenai lalu lintas, khususnya UULLAJ, pengaturan mengenai penetapan korban yang sifatnya sebagai sebuah perlindungan hukum terhadap korban, hanya sebatas pada kriteria korban tanpa melihat ada atau tidaknya penyebab dari kecelakaan lalu lintas tersebut. Hal ini tentu saja dapat menimbulkan ketidakadilan hukum yang didasarkan pada kekaburan aturan hukum.

\section{PERUMUSAN MASALAH}

Berdasarkan uraian latar belakang di atas, maka dirumuskan rumusan masalah sebagai berikut: makna konsep hukum korban menurut doktrin dan pandangan para ahli dan konsep hukum korban dalam perundang-undangan di Indonesia.

\section{PEMBAHASAN}

\section{Konsep Hukum Korban Menurut Doktrin}

Konsep yang menyeluruh tentang korban yang menyeluruh dapat ditemukan dalam Kongres PBB ke-7 yang membicarakan The Prevention of Crime and The Treatment of Offenders di Milan melalui Declaration of Basic Principle of Justice for Victims of Crime and Abuse of Power yang kemudian menjadi Resolusi PBB No. 40/34 yang mendefinisikan korban kejahatan sebagai:
Victims of Crime: 1. Victims means persons who, individual or collectively, have suffered harm, including physical or mental injury, emotional suffering, economic loss or substantial impairment of their fundamental rights, through acts or omissions that are in violation of criminal laws operative within member States, including those laws prescribing criminal abuse of power. 2. A person may be considered a victim, under this Declaration, regardless of whether the perpetrator is identified, apprehended, prosecuted, or convicted and regardless of the familial relationship between the perpetrator and the victim. The term 'victim' also includes, where appropriate, the immediate family, or dependants of the direct victim and persons who have suffered harm in intervening to assist victims in distress or to prevent victimization.

Victims of Abuse of Power: 18. Victims means persons who, individually or collectively, have suffered harm, including physical or mental injury, emotional suffering, economic loss, or substantial impairment of their fundamental rights, through acts or ommisions that do not yet constitute violations of national criminal laws but of internationally recognized norms relating to human rights. ${ }^{6}$

Konsep korban yang telah diatur secara tegas berdasarkan deklarasi tersebut meliputi korban tindak pidana yang sifatnya langsung maupun korban tindak pidana secara tidak langsung baik secara individu maupun secara kelompok. Konsep korban mengalami perluasan makna dimana korban, baik secara individu atau kelompok mengalami penderitaan baik secara fisik maupun mental maupun secara ekonomi serta korban yang mengalami penderitaan akibat penyalahgunaan kekuasaan.

Karakteristik korban langsung adalah: 1. Korban adalah orang, baik secara individu maupun secara kolektif; 2. Menderita kerugian, termasuk: luka fisik, luka mental penderitaan emosional, kehilangan pendapatan, penindasan terhadap hak dasar manusia; 3. Disebabkan oleh adanya perbuatan atau kelalaian yang terumuskan dalam hukum pidana, baik

${ }^{6}$ M. Cherif Bassiouni. The Protection of Human Rights in the Administration of Criminal Justice, dalam C. Maya Indah S. (2014). Perlindungan Korban: Suatu Perspektif Viktiomologi dan Kriminologi. Jakarta: Kencana Prenadamedia Group, h. 29. 
dalam taraf nasional, maupun local levels; atau 4. Disebabkan oleh adanya penyalahgunaan kekuasaan. ${ }^{7}$

Korban tidak langsung yaitu korban dari turut campurnya seseorang dalam membentuk korban langsung atau turut melakukan pencegahan timbulnya korban, tetapi dia sendiri menjadi korban tindak kejahatan, dalam hal ini pihak ketiga, dan/ atau mereka yang menggantungkan hidupnya kepada korban langsung, seperti istri/suami, anak dan keluarga terdekat. ${ }^{8}$

\section{Konsep Korban Menurut Pandangan Para Ahli}

Menurut Arif Gosita, yang dimaksud dengan korban adalah mereka yang menderita jasmaniah dan rohaniah sebagai akibat tindakan orang lain, yang mencari pemenuhan kepentingan diri sendiri atau orang lain, yang bertentangan dengan kepentingan dan hak asasi yang menderita. Pengertian korban disini, dapat berarti sebagai individu atau kelompok baik swasta maupun pemerintah. ${ }^{9}$ Menurut Zvonimir Paul Separovic, korban adalah: “... Those persons who are threatened, injured or destroyed by an act or omission of another (man, structure, organization, or institution) and consequently. A victim would be anyone who has suffered from or been threatened by a punishable act (not only criminal act but also other punishable acts as misdemeanors, economic offences, non-fulfilment of work duties) or from an accident (accident at work, at home, traffic accident, etc.). Suffering may be caused by another man (manmade victim) or another structure, where people are also involved. ${ }^{10}$

Menurut Muladi, korban adalah orang-orang yang baik secara individual maupun kolektif telah menderita kerugian, termasuk kerugian fisik atau mental, emosional, ekonomi, atau gangguan substansial terhadap hak-haknya yang fundamental, melalui perbuatan atau komisi yang melanggar

${ }^{7}$ C. Maya Indah S. (2014). Perlindungan Korban Suatu Perspektif Viktimologi. Jakarta: Kencana Prenada Media Group, h. 30 .

8 ibid., h. 31.

${ }^{9}$ Arif Gosita. (1993). Masalah Korban Kejahatan Kumpulan Karangan. Jakarta: Akademika Pressindo, h. 63.

${ }^{10}$ Zvonimir Paul Separovic. Victimology Studies of Victims, dalam Dr. C. Maya Indah S. (2014). Perlindungan Korban: Suatu Perspektif Viktiomologi dan Kriminologi. Jakarta: Kencana Prenadamedia Group, h. 25. hukum pidana di masing-masing negara, termasuk penyalahgunaan kekuasaan. ${ }^{11}$

Menurut Ezzat Abdel Fattah, tipologi korban dapat dijelaskan sebagai berikut: 1) Nonparticipating victims/korban non partisipatif; 2) Latent or predisposed victims/korban yang bersifat laten; 3) Provocative victims/korban provokatif; 4) Participating victims/korban partisipatif; 5) False victims/korban karena kekeliruan. ${ }^{12}$

Menurut Mendelsohn, keterlibatan korban dalam terjadinya kejahatan dapat dibedakan menjadi enam kategori berdasarkan derajat kesalahannya, yaitu: 1) Korban sama sekali tidak bersalah; 2) Seseorang menjadi korban karena kelalaiannya sendiri; 3) Korban sama salahnya dengan pelaku; 4) Korban lebih bersalah daripada pelakunya; 5) Korban adalah satu-satunya yang bersalah; 6) Korban pura-pura dan korban imajinasi. ${ }^{13}$

Menurut Schaffer, tipologi korban dapat dirinci sebagai berikut:

1) Unrelated Victims, yaitu mereka yang tidak mempunyai hubungan apapun dengan penjahat kecuali jika si penjahat telah melakukan kejahatan terhadapnya.

2) Provocative Victims, yaitu siapa yang melakukan sesuatu terhadap terjadinya pelanggaran, konsekuensinya menjadi perangsang atau mendorong untuk menjadi korban. Misalnya mempunyai "affair" dengan orang lain. Dalam hal ini korban menjadi pelaku utama. Pertanggungjawaban terletak pada pihak korban dan pelaku.

3) Precipitative Victims, yaitu mereka yang secara khusus tidak berbuat sesuatu terhadap penjahat, tetapi tidak terpikirkan bahwa tingkah lakunya mendorong pelaku untuk berbuat jahat terhadap dirinya. Misal, berjalan sendiri di tempat gelap yang sepi dan merangsang penjahat untuk merampok atau memerkosa. Pertanggungjawaban sepenuhnya ada pada pelaku.

${ }^{11}$ Muladi. (1997). Hak Asasi Manusia, Politik dan Sistem Peradilan Pidana. Semarang: Badan Penerbit Universitas Diponegoro, h. 108.

12 Ezzat A. Fattah, dalam C. Maya Indah S. (2014). Perlindungan Korban: Suatu Perspektif Viktiomologi dan Kriminologi. Jakarta: Kencana Prenadamedia Group, h. 26.

${ }^{13}$ Stephen Schaffer. op.cit., h. 35. 
4) Biological Weak Victims, yaitu mereka yang mempunyai bentuk fisik atau mental tertentu yang menyebabkan orang melakukan kejahatan terhadapnya. Misalnya anak kecil, lanjut usia, wanita dan orang cacat. Dalam hal ini pertanggungjawaban terletak pada masyarakat atau pemerintah setempat, karena tidak melindungi para korban yang tidak berdaya.

5) Socially Weak Victims, merupakan orang-orang yang tidak diperhatikan oleh masyarakat luas sebagai anggota dalam masyarakat tersebut. Misalnya para imigran, penganut agama tertentu, dan minoritas etnis yang mempunyai kedudukan sosial yang lemah. Dalam kondisi ini, pertanggungjawaban penuh terletak pada penjahat atau masyarakat.

6) Self-victimizing Victims, yaitu mereka yang menjadi korban karena kejahatan yang dilakukan sendiri. Beberapa literatur menyatakan ini sebegai kejahatan tanpa korban. Akan tetapi pandangan ini menjadi dasar pemikiran bahwa tidak ada kejahatan tanpa korban. Semua/setiap kejahatan melibatkan dua hal, yaitu penjahat dan korban. Contoh pecandu obat bius, homoseks, alkoholik, dan judi. Pertanggungjawaban terletak penuh pada si pelaku, yang juga sekaligus menjadi korban.

7) Political Victims, yaitu mereka yang menderita karena lawan politiknya. Korban ini secara sosiologis tidak dapat dipertanggungjawabkan. ${ }^{14}$

\section{Konsep Hukum Korban Menurut Perundang- Undangan di Indonesia}

1. Konsep hukum korban menurut UndangUndang No. 13 Tahun 2006 tentang Perlindungan Saksi dan Korban

Menurut Pasal 1 angka 3 Undang - undang No. 13 Tahun 2016 tentang Perlindungan Saksi dan Korban (UU PSK), definisi dari korban adalah: "Korban adalah orang yang mengalami penderitaan fisik, mental, dan/atau kerugian ekonomi yang diakibatkan oleh suatu tindak pidana”.

Berdasarkan definisi korban menurut UU PSK tersebut, dapat ditarik unsur-unsur yang membentuk suatu konsep korban yaitu:

1) Orang. Orang yang dimaksud dalam UU PSK adalah setiap individu atau kelompok.

\footnotetext{
14 ibid., h. 35.
}

2) Mengalami penderitaan fisik, mental, dan/atau kerugian ekonomi. Penderitaan yang dialami oleh seseorang ataupun kelompok merupakan penderitaan yang menyerang fisik atau tubuh yang dapat mengakibatkan luka-luka baik luka ringan maupun luka berat dan juga penderitaan yang menyerang kondisi psikis atau mental seperti misalnya trauma berat atau bahkan dapat menimbulkan gangguan kejiwaan. Dalam hal penderitaan yang dialami, dapat pula terjadi kerugian secara ekonomi atau materiil yaitu kerugian yang dapat dihitung secara ekonomi.

3) Diakibatkan oleh suatu tindak pidana. Unsur tindak pidana merupakan unsur yang tak dapat dipisahkan dengan konsep korban. Dalam suatu tindak pidana, terdapat suatu perbuatan yang dilakukan oleh seseorang atau sekelompok orang yang melawan hukum dengan melanggar undangundang yang kemudian dapat menimbulkan kerugian bagi pihak lain yang kemudian menjadi korban. Dalam tindak pidana akan terdapat pihak yang melakukan sebagai pelaku tindak pidana dan pihak yang dirugikan sebagai korban tindak pidana. Unsur tindak pidana merupakan unsur yang sifatnya mutlak dalam menentukan pelaku terlebih korban sehingga korban pada intinya merupakan pihak yang dirugikan akibat perbuatan yang dilakukan oleh pihak lain.

\section{Konsep korban menurut Undang-Undang No. 23 Tahun 2004 tentang Penghapusan Kekerasan Dalam Rumah Tangga}

Konsep korban di dalam UU Penghapusan KDRT diatur dalam Pasal 1 angka 3 yang berbunyi: "Korban adalah orang yang mengalami kekerasan dan/atau ancaman kekerasan dalam rumah tangga." Berangkat dari konsep yang terdapat dalam UU Penghapusan KDRT tersebut, maka dapat ditarik kesimpulan bahwa konsep korban menurut UU Penghapusan KDRT terdiri dari:

1) Orang. Orang yang dimaksud dalam undangundang ini adalah tiap individu yang terikat dalam perkawinan yang sah.

2) Mengalami kekerasan dan/atau ancaman kekerasan dalam rumah tangga. Kekerasan yang ada dalam ketentuan ini tidak hanya terbatas pada kekerasan fisik, melainkan juga kekerasan verbal yang berupa hinaan, makian, kata-kata 
yang merendahkan dan dapat pula dalam bentuk ancaman.

Berdasarkan definisi mengenai korban yang terdapat dalam rumusan di atas, maka dapat ditarik suatu konsep bahwa korban adalah setiap orang yang mengalami kerugian akibat adanya kekerasan dan/ atau ancaman yang dilakukan oleh pasangannya yang berada dalam satu ikatan perkawinan yang sah.

\section{Konsep korban menurut Undang-Undang No. 21 Tahun 2007 tentang Tindak Pidana Perdagangan Orang}

Dalam Undang-Undang No. 21 Tahun 2007 tentang Tindak Pidana Perdagangan Orang, selain mengatur tentang kualifikasi tindak pidana perdagangan orang, diatur pula mengenai definisi tentang korban khususnya korban tindak pidana perdagangan orang yaitu: "Korban adalah seseorang yang mengalami penderitaan psikis, mental, fisik, seksual, ekonomi, dan/atau sosial, yang diakibatkan tindak pidana perdagangan orang". Berdasarkan definisi yang diatur dalam undang-undang ini, maka konsep korban yang dapat dikemukakan adalah bahwa untuk dapat dikategorikan sebagai korban, maka harus terdapat 3 unsur yaitu: 1) Orang yang bersifat individu atau kelompok; 2) Mengalami kerugian (fisik/psikis/ekonomi/sosial);

3) Diakibatkan oleh adanya tindak pidana.

Berdasarkan unsur-unsur tersebut, terdapat suatu kejelasan akan kedudukan korban dalam suatu tindak pidana. Penentuan kedudukan korban bukan hanya sekedar bertumpu pada adanya kerugian yang dialami oleh individu atau kelompok, melainkan juga melihat dan menakar terlebih dahulu bahwa kerugian yang muncul adalah akibat langsung dari tindak pidana yang dilakukan oleh pihak lain.

\section{Konsep korban menurut Kitab Undang- Undang Hukum Pidana}

Di dalam KUHP, tidak ditemukan adanya suatu klausul yang menjelaskan definisi dari korban tindak pidana secara implisit. Namun demikian, terdapat beberapa ketentuan antara lain:

Pasal $14 \mathrm{c}$ ayat (1) yang berbunyi: "Pada perintah yang tersebut dalam Pasal 14 a kecuali dalam hal dijatuhkan pidana denda, maka bersama-sama dengan syarat umum, bahwa orang yang dipidana, hakim boleh mengadakan syarat khusus bahwa orang yang dipidana itu akan mengganti kerugian yang terjadi karena tindak pidana itu, semuanya atau sebagian saja, yang akan ditentukan pada perintah yang ditentukan pada itu juga, yang kurang dari masa percobaan itu."

Berdasarkan ketentuan pasal tersebut, secara tidak langsung terdapat perlindungan terhadap korban tindak pidana sekalipun tidak dinyatakan secara tegas dalam keseluruhan KUHP mengenai definisi dari korban. Di dalam ketentuan pasal tersebut, dapat ditarik konsep korban secara tidak langsung yaitu:

1) Tindak pidana. Di dalam ketentuan Pasal $14 \mathrm{c}$ ayat (1) tersebut, secara tersirat terdapat adanya frasa "tindak pidana". Hal ini berarti bahwa adanya suatu tindakan yang melawan hukum yang dilakukan oleh seseorang atau sekelompok orang.

2) Kerugian. Di dalam ketentuan pasal $14 \mathrm{c}$ ayat (1) tersebut, terdapat frasa "kerugian yang terjadi karena tindak pidana itu”. Dengan demikian, terdapat unsur kerugian yang dialami oleh pihak yang merasa dirugikan akibat telah dilakukannya tindak pidana tersebut.

Pasal 72 KUHP, ayat (1) Selama orang yang terkena kejahatan yang hanya boleh dituntut atas pengaduan, dan orang itu umurnya belum cukup enam belas tahun dan lagi belum dewasa, atau selama ia berada di bawah pengampuan yang disebabkan oleh hal lain daripada keborosan, maka wakilnya yang sah dalam perkara perdata yang berhak mengadu; ayat (2) Jika tidak ada wakil, atau wakil itu sendiri yang harus diadukan, maka penuntutan dilakukan atas pengaduan wali pengawas atau pengampu pengawas, atau majelis yang menjadi wali pengawas atau pengampu pengawas; juga mungkin atas pengaduan istrinya atau seorang keluarga sedarah dalam garis lurus, atau jika itu tidak ada, atas pengaduan seorang keluarga sedarah dalam garis menyimpang sampai derajat ketiga.

Tindak pidana aduan diatur di dalam KUHP khusus mengatur masalah tindak pidana yang tergolong sebagai tindak pidana aduan. Menurut Van Hamel, pada umumnya orang berhak mengadukan suatu delik aduan kepada penyidik ialah orang yang menurut sifat kejahatannya secara langsung telah 
menjadi korban atau telah dirugikan oleh kejahatan tersebut. $^{15}$

\section{Konsep korban menurut Undang-Undang No. 8 Tahun 1981 tentang Kitab Undang-Undang Hukum Acara Pidana}

Di dalam KUHAP, tidak terdapat ketentuan yang secara tegas memberikan definisi tentang korban. Namun demikian, terdapat beberapa pasal yang secara tidak langsung mengatur karakteristikkarakteristik korban.

Pasal-pasal yang mengatur tentang karakteristik korban antara lain:

a. Korban Sebagai Pihak Pelapor. Pasal 108 KUHAP: Setiap orang yang mengalami, melihat, menyaksikan dan atau menjadi korban peristiwa yang merupakan tindak pidana berhak untuk mengajukan laporan atau pengaduan kepada penyelidik dan atau penyidik baik lisan maupun tertulis.

Berdasarkan ketentuan dari pasal ini, maka hak yang terutama bagi orang yang mengalami, melihat, menyaksikan dan atau menjadi korban peristiwa yang merupakan tindak pidana adalah untuk membuat laporan kepada penyidik. Definisi ini memiliki kemiripan dengan definisi korban yang berasal dari pemikiran viktimologi yang dipengaruhi kriminologi yang bersifat positivis yang menitikberatkan bahwa peristiwa yang dialami oleh korban adalah merupakan perbuatan jahat yang telah dirumuskan dan dapat dipidana dalam hukum pidana. ${ }^{16}$

b. Korban Sebagai Pihak Ketiga yang Berkepentingan. Pasal 80 KUHAP: Permintaan untuk memeriksa sah atau tidaknya suatu penghentian penyidikan atau penuntutan dapat diajukan oleh penyidik atau penuntut umum atau pihak ketiga yang berkepentingan kepada ketua pengadilan negeri dengan menyebutkan alasannya.

Pasal 81 KUHAP: Permintaan ganti kerugian dan atau rehabilitasi akibat tidak sahnya penangkapan atau penahanan atau akibat

15 G.A. Van Hamel. Inleiding tot de Studie van het Nederlandsche Strafrecht, dalam Andi Hamzah. (2017). Hukum Pidana Indonesia. Jakarta: Sinar Grafika, h. 233.

16 Richard Quinney. Who is the Victim, dalam C. Maya Indah. op.cit., h. 27. sahnya penghentian penyidikan atau penuntutan diajukan oleh tersangka atau pihak ketiga yang berkepentingan kepada ketua pengadilan negeri dengan menyebut alasannya.

Berdasarkan ketentuan yang terdapat dalam pasal-pasal tersebut, terdapat perluasan mengenai subyek korban di mana korban dalam hal ini bukan hanya terbatas pada orang dengan kedudukan biasa melainkan juga orang dalam kedudukannya sebagai penyidik atau penuntut umum. Di dalam perkembangan ruang lingkup viktimologi, paradigma mengenai korban mengalami perluasan, yaitu meliputi bagaimana seseorang (dapat) menjadi korban atau berfokus pada proses terjadinya viktimisasi yang bukan hanya karena kejahatan, melainkan juga karena penyalahgunaan kekuasaan atau bekerjanya lembaga dan pranata hukum yang tidak berkeadilan. ${ }^{17}$

Melalui eksistensi berlakunya KUHAP, maka korban dimungkinkan mengontrol suatu perkara yang menempatkan dirinya sebagai korban seperti melakukan upaya pra peradilan, jika suatu perkara dihentikan penyidikan atau penuntutannya. Hal tersebut merupakan salah satu bentuk perlindungan karena diberikannya hak kontrol ini dapat memberi jaminan bahwa perkara pidana dimaksud dapat diselesaikan berdasarkan hukum yang berlaku. ${ }^{18}$

c. Korban Sebagai Pihak Ketiga yang Dirugikan. 1) Pasal 98 ayat (1): Jika suatu perbuatan yang menjadi dasar dakwaan di dalam suatu pemeriksaan perkara pidana oleh pengadilan negeri menimbulkan kerugian bagi orang lain, maka hakim ketua sidang atas permintaan orang itu dapat menetapkan untuk menggabungkan perkara gugatan. 2) Pasal 99 ayat (1): Apabila pihak yang dirugikan minta penggabungan perkara gugatannya pada perkara pidana sebagaimana dimaksud dalam Pasal 98, maka Pengadilan Negeri menimbang tentang kewenangannya untuk mengadili gugatan tersebut, tentang kebenaran dasar gugatan dan

17 J.E. Sahetapy. Viktimologi Sebuah Bunga Rampai, dalam C. Maya Indah S. Perlindungan Korban Suatu Perspektif Viktimologi dan Kriminologi. (2014). Jakarta: Kencana Prenada Media Group, h. 21

${ }^{18}$ Lilik Mulyadi. (2012). Bunga Rampai Hukum Pidana Umum dan Khusus. Bandung: Alumni. Bandung, h. 170. 
tentang hukuman penggantian biaya yang telah dikeluarkan oleh pihak yang dirugikan tersebut.

Dalam praktek yang terjadi di kehidupan nyata, tidak jarang tindak pidana yang dilakukan oleh seseorang atau sekelompok orang menimbulkan dampak kerugian yang dialami tidak hanya oleh korban secara langsung, melainkan pihak ketiga yang sama sekali tidak bersalah dan tidak terlibat, contohnya istri dan anak dari korban yang meninggal dunia atau pun mengalami cacat akibat tindak pidana yang dilakukan oleh seseorang atau sekelompok orang. Namun dalam bab mengenai Penjelasan dalam KUHAP tidak diatur secara jelas mengenai orang lain atau pihak ketiga yang dirugikan.

Menurut Declaration of Basic Principle of Justice for Victims of Crime and Abuse of Power, dinyatakan bahwa pengertian Victims of Crime: 1. Victims means persons who, individual or collectively, have suffered harm, including physical or mental injury, emotional suffering, economic loss or substansial impairment of their fundamental rights, through acts or omissions that are in violation of criminal laws operative within member States, including those laws prescribing criminal abuse of power. 2. A person may be considered a victim, under this Declaration, regardless of whether the perpetrator is identified, apprehended, prosecuted, or convicted and regardless of the familial relationship between the perpetrator and the victim. The term 'victim'also includes, where appropriate, the immediate family, or dependants of the direct victim and persons who have suffered harm in intervening to assist victims in distress or to prevent victimization.

Berdasarkan definisi tersebut, dapat ditarik suatu kesimpulan yaitu bahwa terdapat 2 (dua) jenis korban yaitu korban tindak pidana secara langsung (direct victims of crime) dan korban tindak pidana yang tidak langsung (indirect victims of crime). Korban tindak pidana langsung (direct victims) yaitu korban yang langsung mengalami dan merasakan penderitaan dengan adanya tindak pidana kejahatan. Korban tindak pidana langsung memiliki karakteristik: 1 . Korban adalah orang, baik secara individu maupun secara kolektif; 2. Menderita kerugian, termasuk: luka fisik, luka mental, penderitaan emosional, kehilangan pendapatan, penindasan terhadap hak dasar manusia; 3. Disebabkan oleh adanya perbuatan atau kelalaian yang terumuskan dalam hukum pidana, baik dalam taraf nasional, maupun local levels; atau 4. Disebabkan oleh adanya penyalahgunaan kekuasaan.

Sedangkan korban tidak langsung (indirect victims) yaitu korban dari turut campurnya seseorang dalam membentuk korban langsung (direct victims) atau turut melakukan pencegahan timbulnya korban, tetapi dia sendiri menjadi korban tindak kejahatan, dalam hal ini pihak ketiga, dan/atau mereka yang menggantungkan hidupnya kepada korban langsung (direct victims), seperti istri/suami, anak, dan keluarga terdekat. ${ }^{19}$

Pihak keluarga seperti istri/suami, anak, dan keluarga terdekat yang menjadi korban secara tidak langsung, berdasarkan ketentuan pasal ini dalam KUHAP, dapat mengajukan gugatan sebagai bentuk protes akan kerugian yang dialami. Berdasarkan ketentuan ini, maka gugatan yang diajukan ke pengadilan dapat digabungkan dengan dakwaan pidana yang ditetapkan kepada terdakwa yang kemudian akan menjadi bahan pertimbangan hakim bahwa dasar dari kerugian yang digugat merupakan hasil dari tindak pidana yang didakwakan kepada terdakwa.

\section{Korban sebagai saksi korban}

Berdasarkan Pasal 160 ayat (1): a. Saksi dipanggil ke dalam ruang sidang seorang demi seorang menurut urutan yang dipandang sebaik-baiknya oleh hakim ketua sidang setelah mendengar pendapat penuntut umum, terdakwa atau penasihat hukum; b. Yang pertama-tama didengar keterangannya adalah korban yang menjadi saksi; c. Dalam hal ada saksi baik yang menguntungkan maupun yang memberatkan terdakwa yang tercantum dalam surat pelimpahan perkara dan atau yang diminta oleh terdakwa atau penasihat hukum atau penuntut umum selama berlangsungnya sidang atau sebelum dijatuhkannya putusan, hakim ketua sidang wajib mendengar keterangan saksi tersebut.

Berdasarkan ketentuan dalam pasal ini maka kedudukan korban semata-mata hanyalah merupakan sebagai saksi dari suatu perkara pidana untuk membuktikan kesalahan tersangka atau terdakwa. Dalam hal ini, selain sebagai pelapor yang merupakan orang yang mengalami, melihat atau menyaksikan peristiwa tindak pidana yang terjadi dan menimpa

\footnotetext{
${ }^{19}$ C. Maya Indah. op.cit., h. 31.
} 
kepadanya, korban juga berperan sebagai saksi pasif di mana korban hadir bila diminta dan juga perannya terbatas hanya memberikan keterangan mengenai sesuatu yang dilihat, didengar dan dialaminya sendiri. ${ }^{20}$

\section{Konsep korban menurut UULAJ}

Di dalam UULAJ, tidak terdapat adanya definisi yang secara tegas mengatur mengenai konsep korban. Namun demikian, terdapat konsep korban yang dapat ditarik dari beberapa pasal antara lain:

1. Pasal 229 ayat (4): (1) Kecelakaan Lalu Lintas digolongkan atas: a. Kecelakaan Lalu Lintas ringan; b. Kecelakaan Lalu Lintas sedang; atau c. Kecelakaan Lalu Lintas berat; (2) Kecelakaan Lalu Lintas ringan sebagaimana dimaksud pada ayat (1) huruf a merupakan kecelakaan yang mengakibatkan kerusakan Kendaraan dan/atau barang; (3) Kecelakaan Lalu Lintas sedang sebagaimana dimaksud pada ayat (1) huruf b merupakan kecelakaan yang mengakibatkan luka ringan dan kerusakan Kendaraan dan/ atau barang; (4) Kecelakaan Lalu Lintas berat sebagaimana dimaksud pada ayat (1) huruf c merupakan kecelakaan yang mengakibatkan korban meninggal dunia atau luka berat.

2. Penjelasan Pasal 229 ayat (3) dan (4). Ayat (3): Yang dimaksud dengan "luka ringan" adalah luka yang mengakibatkan korban menderita sakit yang tidak memerlukan perawatan inap di rumah sakit atau selain yang diklasifikasikan dalam luka berat.

Ayat (4): Yang dimaksud dengan "luka berat" adalah luka yang mengakibatkan korban: a. jatuh sakit dan tidak ada harapan sembuh sama sekali atau menimbulkan bahaya maut; b. tidak mampu terus-menerus untuk menjalankan tugas jabatan atau pekerjaan; c. kehilangan salah satu pancaindra; d. menderita cacat berat atau lumpuh; e. terganggu daya pikir selama 4 (empat) minggu lebih; f. gugur atau matinya kandungan seorang perempuan; atau g. luka yang membutuhkan perawatan di rumah sakit lebih dari 30 (tiga puluh) hari.

3. Pasal 231 ayat (1): (1) Pengemudi Kendaraan Bermotor yang terlibat Kecelakaan Lalu Lintas, wajib: a. menghentikan Kendaraan yang

\footnotetext{
${ }^{20}$ Lilik Mulyadi. op.cit., h. 170.
}

dikemudikannya; b. memberikan pertolongan kepada korban; c. melaporkan kecelakaan kepada Kepolisian Negara Republik Indonesia terdekat; dan d. memberikan keterangan yang terkait dengan kejadian kecelakaan.

4. Pasal 235 ayat (1) dan (2): (1) Jika korban meninggal dunia akibat Kecelakaan Lalu Lintas sebagaimana dimaksud dalam Pasal 229 ayat (1) huruf c, Pengemudi, pemilik, dan/atau Perusahaan Angkutan Umum wajib memberikan bantuan kepada ahli waris korban berupa biaya pengobatan dan/atau biaya pemakaman dengan tidak menggugurkan tuntutan perkara pidana.

(2) Jika terjadi cedera terhadap badan atau kesehatan korban akibat Kecelakaan Lalu Lintas sebagaimana dimaksud dalam Pasal 229 ayat (1) huruf b dan huruf c, pengemudi, pemilik, dan/atau Perusahaan Angkutan Umum wajib memberikan bantuan kepada korban berupa biaya pengobatan dengan tidak menggugurkan tuntutan perkara pidana.

Berangkat dari ketentuan-ketentuan yang terdapat dalam pasal-pasal tersebut, maka dapat ditarik suatu kesimpulan mengenai konsep korban yang terdapat dalam UULLAJ yaitu bahwa korban adalah setiap orang yang menderita luka, baik luka ringan maupun berat dan orang yang meninggal dunia akibat adanya sebuah kecelakaan lalu lintas.

Konsep mengenai korban yang terdapat dalam UULLAJ merupakan konsep yang menjadi permasalaha terkait adanya kecelakaan lalu lintas. Hal ini disebabkan dari konsep korban yang terbentuk dari UULLAJ tersebut yaitu setiap orang yang mengalami luka baik luka ringan maupun luka berat selalu diposisikan sebagai korban kecelakaan lalu lintas tanpa mengindahkan atau menitikberatkan pada kesalahan di mana terkadang justru korban yang mengalami luka berat atau luka ringan ataupun meninggal dunia adalah pihak yang menjadi pemicu yang bersalah menyebabkan kecelakaan itu sendiri.

Pihak korban terkadang dalam terjadinya tindak pidana atau kejahatan, terkadang memiliki tanggung jawab fungsional akibat pihak korban yang memiliki keterlibatan sebagai pemicu kejahatan. Menurut teori criminal-function relationship, maka korban memiliki kategori derajat kesalahan yaitu: 1) Korban sama sekali tidak bersalah; 2) Seseorang menjadi korban karena kelalaiannya sendiri; 3) Korban sama 
salahnya dengan pelaku; 4) Korban lebih bersalah daripada pelakunya; 5) Korban adalah satu-satunya yang bersalah; 6) Korban pura-pura dan korban imajinasi. ${ }^{21}$

Berangkat dari kualifikasi ini maka, pihak korban kecelakaan lalu lintas terkadang dapat dikategorikan sebagai pihak yang menjadi korban karena kelalaiannya sendiri yang akhirnya memicu kecelakaan lau lintas atau dapat pula menjadi pihak yang lebih bersalah dari pelakunya dalam hal contohnya: pengemudi sepeda motor yang melanggar rambu lalu lintas dengan menerobos lampu merah, atau berada dalam kondisi mabuk akibat minuman beralkohol yang akhirnya menimbulkan tabrakan dengan mobil atau kendaraan lain yang melukai dirinya sendiri dan mengakibatkan kerusakan kendaraan lain.

\section{PENUTUP}

\section{Kesimpulan}

Konsep korban secara umum adalah setiap orang yang mengalami penderitaan fisik berupa luka ringan, luka berat atau kematian.

Konsep korban yang terdapat dalam UULLAJ tidak sesuai dengan konsep korban yang terdapat dalam beberapa aturan perundangan di Indonesia yang hanya mengatur bahwa korban adalah setiap orang yang mengalami luka berat, luka sedang dan atau meninggal dunia. Konsep yang diatur dalam UULLAJ hanya menitikberatkan pada korban sebagai orang yang mengalami luka fisik yang cenderung secara langsung menempatkan orang yang luka sebagai pihak yang menjadi korban dan pihak yang melakukan akan sebagai orang yang salah.

Konsep korban dalam UULLAJ harus bersifat mengatur secara menyeluruh terutama mengenai korban. Konsep mengenai korban dalam UULLAJ yang cenderung menitikberatkan pada luka-luka memerlukan adanya pengaturan yang lebih luas sehingga tidak serta merta menempatkan orang yang luka-luka sebagai korban melainkan perlu diatur pula mengenai hubungan korban dengan pelaku kecelakaan lalu lintas.

\section{Rekomendasi}

Penerapan konsep korban merupakan hal yang krusial dalam rangka memberikan perlindungan hukum khususnya terkait dalam hal berlalu lintas. Karakteristik-karakteristik korban perlu mendapat kajian khusus agar benar-benar sesuai dengan konsep korban dalam menentukan kedudukan korban. Perlu kiranya dilakukan judicial review bagi UULLAJ agar pengaturan konsep korban yang terdapat di dalamnya sesuai dan harmonis dengan konsep korban secara umum menurut kajian ilmu viktimologi maupun peraturan perundangan yang lainnya.

\section{DAFTAR PUSTAKA}

\section{Peraturan Perundang-undangan:}

Undang-Undang Dasar Negara Republik Indonesia Tahun 1945.

Kitab Undang-Undang Hukum Pidana.

Undang-Undang Nomor 8 Tahun 1981 tentang Kitab Undang-Undang Hukum Acara Pidana.

Undang-Undang Nomor 23 Tahun 2004 tentang Penghapusan Kekerasan Dalam Rumah Tangga.

Undang-Undang Nomor 13 Tahun 2006 tentang Perlindungan Saksi dan Korban.

Undang-Undang Nomor 22 Tahun 2009 tentang Lalu Lintas dan Angkutan Jalan.

\section{Buku:}

A.V. Dicey. The Relation Between Law and Public Opinion, dalam Lilik mulyadi. (2012). Bunga Rampai Hukum Pidana Umum dan Khusus. Bandung: Alumni.

Arif Gosita. (1993). Masalah Korban Kejahatan Kumpulan Karangan. Jakarta: Akademika Pressindo.

C. Maya Indah S. (2014). Perlindungan Korban Suatu Perspektif Viktimologi dan Kriminologi. Jakarta: Kencana Prenada Media Group.

Darji Darmodihardjo dan Sidharta. (1999). PokokPokok Filsafat Hukum: Apa dan Bagaimana Filsafat Hukum Indonesia. Jakarta: Gramedia Pustaka Utama.

Ezzat A. Fattah, dalam C. Maya Indah S. (2014). Perlindungan Korban: Suatu Perspektif Viktiomologi dan Kriminologi. Jakarta: Kencana Prenadamedia Group.

G.A. Van Hamel. Inleiding tot de Studie van het Nederlandsche Strafrecht, dalam Andi Hamzah. 2017. Hukum Pidana Indonesia. Jakarta: Sinar Grafika.

\footnotetext{
${ }^{21}$ Schaffer. op.cit., h. 35.
} 
J.E. Sahetapy. Viktimologi Sebuah Bunga Rampai, dalam C. Maya Indah S. (2014). Perlindungan Korban Suatu Perspektif Viktimologi dan Kriminologi. Jakarta: Kencana Prenada Media Group.

Lilik Mulyadi. (2012). Bunga Rampai Hukum Pidana Umum dan Khusus. Bandung: Alumni. Bandung.

M. Cherif Bassiouni. The Protection of Human Rights in the Administration of Criminal Justice, dalam C. Maya Indah S. (2014). Perlindungan Korban: Suatu Perspektif Viktiomologi dan Kriminologi. Jakarta: Kencana Prenadamedia Group.

Muladi. (1997). Hak Asasi Manusia, Politik dan Sistem Peradilan Pidana. Semarang: Badan Penerbit Universitas Diponegoro, Semarang.
Oemar Seno Adjie. (1980). Peradilan Bebas Negara Hukum. Jakarta: Erlangga.

Richard Quinney. Who is the Victim, dalam C. Maya Indah.

Simorangkir. (1986). Hukum dan Konstitusi Indonesia. Jakarta: Gunung Agung.

Sri Soemantri Martosoewignjo. (1992). Bunga Rampai Hukum Tata Negara Indonesia. Bandung: Alumni.

Zvonimir Paul Separovic. Victimology Studies of Victims, dalam C. Maya Indah S. (2014). Perlindungan Korban: Suatu Perspektif Viktiomologi dan Kriminologi. Jakarta: Kencana Prenadamedia Group. 